\title{
ENVIRONMENTAL ASSESSMENT
}

Construction of Mixed Waste Storage RCRA Facilities,

Buildings 7668 and 7669

U.S. Department of Energy

Oak Ridge National Laboratory

Oak Ridge, Tennessee

April 1994

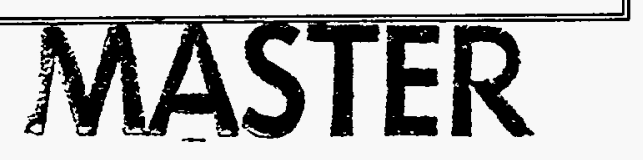

DISTRISUTRSA OF THIS DOCUMENT IS UNLIMITED 


\section{DISCLAIMER}

This report was prepared as an account of work sponsored by an agency of the United States Government. Neither the United States Government nor any agency thereof, nor any of their employees, make any warranty, express or implied, or assumes any legal liability or responsibility for the accuracy, completeness, or usefulness of any information, apparatus, product, or process disclosed, or represents that its use would not infringe privately owned rights. Reference herein to any specific commercial product, process, or service by trade name, trademark, manufacturer, or otherwise does not necessarily constitute or imply its endorsement, recommendation, or favoring by the United States Government or any agency thereof. The views and opinions of authors expressed herein do not necessarily state or reflect those of the United States Government or any agency thereof. 


\section{DISCLAIMER}

Portions of this document may be illegible in electronic image products. Images are produced from the best available original document. 
OATE: August 16, 1994

REPLY TO

ATTN OF: Office of NEPA Oversight: Osborne: 6-4596

subuect: Environmental Assessment for the Proposed Construction and Operation of Mixed Waste Storage Facilities at the Oak Ridge National Laboratory, Oak TO: Ridge, Tennessee (DOE/EA-0947)

Thomas P. Grumbly

Assistant Secretary for Environmental Management

On April 15, 1994, the Office of NEPA Oversight authorized a 30-day preapproval review of the subject environmental assessment by the State of Tennessee, and on May 9, 1994, you transmitted the environmental assessment to Tennessee. Michael Kleinrock of your NEPA Compliance Officer's staff informed us on July 1, 1994, that no comments were received from the state and requested that we proceed with approval of the envirenmental assessment and issuance of a finding of no significant impact.

The Office of Environment, Safety and Health has reviewed the environmental assessment (dated April 1994) in accordance with our responsibilities under DOE 5440.1E. Based upon my staff's review and recommendations, and after consultation with the Office of General Counsel, I have determined that the environmental assessment is adequate for publication and is hereby approved. I have also determined that the proposed action is not a major Federal action significantly affecting the quality of the human environment, within the meaning of the National Environmental Policy Act. Therefore, the preparation of an environmental impact statement is not required. The basis for this determination is explained in the attached finding of no significant impact.

Please note that the Office of Environmental Management is responsible for providing public notice of the availability of the environmental assessment and finding of no significant impact in accordance with 40 CFR 1506.6(b), 10 CFR 1021.322, and DOE 5440.1E, paragraph 6A (24). Please provide an electronic file and five copies of the environmental assessment, and a record of distribution of the environmental assessment and finding of no significant impact to the Office of NEPA Oversight for our files.

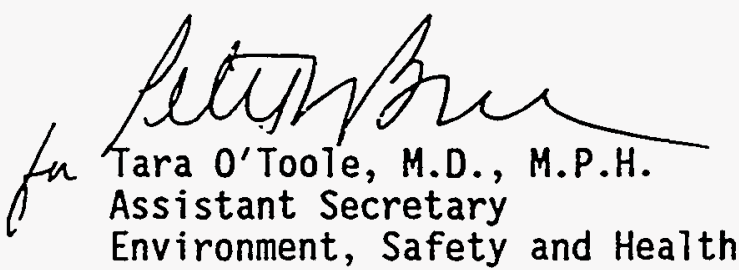

Attachment

cc: Randal Scott, EM-20, NEPA Compliance Officer Patty Phillips, OR, NEPA Compliance officer 


\section{FINDING OF NO SIGNIFICANT IMPACT \\ FOR CONSTRUCTION OF MIXED YASTE STORAGE FACILITIES, \\ BUILDINGS 7668 AND 7669 \\ OAK RIDGE MATIONAL LABORATORY \\ OAK RIDGE, TENHESSEE}

AGENCY: Department of Energy

ACTION: Finding of No Significant Impact

SURAARY: The Department of Energy has prepared an environmental assessment, DOE/EA-0820, to assess the potential environmental impacts of constructing and operating two mixed waste Resource Conservation and Recovery Act (RCRA) storage facilities. The new facilities would be located inside and immediately west of the security-fenced area of the Oak Ridge National Laboratory Hazardous Waste Management Area in Melton Valley, Tennessee. Based on the analyses in the environmental assessment, the Department has determined that the proposed action does not constitute a major Federal action significantiy affecting the quality of the human environment within the meaning of the National Environmental Policy Act of 1969. Therefore, the preparation of an environmental impact statement is not required, and the Department is issuing this finding of no significant impact.

\section{COPIES OF THE ENVIRONMENTAL ASSESSMERT ARE AVAILABLE FROM:}

\section{Information Resource Center}

U.S. Department of Energy

105 Broadway

Oak Ridge, TN 37830

Phone: (615) 481-0695

FOR FURTHER INFORMATION ON THE DEPARTMENT'S NATIONAL ENVIRONMENTAL POLICY ACT PROCESS, CONTACT:

Ms. Carol M. Borgstrom, Director

Office of NEPA Oversight, EH-25

U.S. Department of Energy

1000 Independence Avenue, S.W.

Washington, DC 20585

Phone: (202) $586-4600$ or leave a message at (800) $472-2756$ 
PROPOSED ACTION: The proposed action is to construct and operate two mixed (both radioactive and hazardous) waste storage facilities (Buildings 7668 and 7669) in accordance with RCRA requirements. The new facilities would be sized to hold a total of 75055 -gal drums, or 41,250 gal of mixed waste. Building 7668 would store about 500 drums, and Building 7669 would store about 250 drums. Drums would be stored four drums to a 4-foot by 4-foot pallet stacked two pallets high. One air exchange per hour would be provided in each building, and the ventilation exhaust would pass through a high-efficiency particulate air filtration system. Operation of the facilities would involve off-loading of mixed waste drums from a transport vehicle and movement of the drums to a storage location by forklift. Operation would also include routine inspections, monitoring procedures, and building maintenance.

ENVIRONHENTAL IMPACTS: Site preparation and construction activities would be conducted within a previously developed and disturbed area and would not affect environmentaliy sensitive resources, such as archeological or historic sites, habitats of any threatened or endangered species, floodplains, or wetlands. Existing surface water drainage patterns would be minimally altered as a result of the construction activities, since no surface streams are in the immediate area.

Pollutant emissions during construction would be temporary and would consist primarily of particulates released during earth-moving activities.

Appropriate dust suppression techniques would be utilized. Spill prevention, control, containment, and cleanup measures would be used to control the effects of any accidental spills of hydraulic fluid, lubricating oil, etc., during construction.

Occupational exposure from handling mixed waste in the new facilities is expected to be similar to that of existing operations. Waste would be stored in containers approved for mixed and hazardous waste and would be limited to a maximum dose rate of less than $10 \mathrm{mrem} / \mathrm{h}$ on the outside surface of the waste container. The occupational exposures for the Hazardous Waste Management Area facilities are monitored using personal thermoluminescence dosimeters, and 
Laboratory policy limits exposure to no more than 2 rem/year for each employee. In 1990, the average occupational dose for waste workers was $22 \mathrm{mrem}$; the maximum occupational dose received by an individual worker was $149 \mathrm{mrem}$; and the minimum was 0 mrem. Buildings 7668 and 7669 would be operated under RCRA permits. The permits require facilities to comply with 40 CFR Part 265 (or applicable state regulations), which specifies minimum standards for safe operations, including security, personnel training, and alarm systems.

The hazards identified with operating the proposed 7668 and 7669 facilities are the same as those encountered with the Long-Term Hazardous Waste Storage Facility, Building 7654 (Reference 8 in the environmental assessment), since the same drummed co-contaminated wastes are being stored in Building 7654 as would be stored in Buildings 7668 and 7669 . Building 7654 has undergone a hazard screening, resulting in a determination that radiation dose consequences of an accident at 100 meters would be much less than 10 rem. This would result in a cancer risk of less than $5 \times 10^{-3}$ lifetime cancer risk to on-site personnel beyond 100 meters downwind and much less than $5 \times 10^{-5}$ to off-site members of the public for one-time exposure to accidental releases from Building 7654.

Based on a typical inventory, chemical hazards were also investigated. The chemicals expected to be stored in Buildings 7668 and 7669 are considered toxic chemicals; no carcinogens would be stored in these facilities. Exposure of personnel to toxic contaminants from the proposed storage facilities is not anticipated. Therefore, no adverse effect on workers, or the public, is expected from the hazardous components of the mixed waste to be stored under the proposed action.

ALTERNATIVES CONSIDERED: Alternatives considered in the review of the proposed action were (1) no action and (2) alternative sites at the Laboratory. Taking no action would result in the storage of mixed waste in facilities without RCRA permits resulting in noncompliance with RCRA requirements. Existing RCRA-permitted storage facilities are near capacity and mixed waste generation cannot be curtailed due to the mandatory 
environmental restoration activity at the Laboratory. Alternative sites are less disturbed than the proposed site and are not within or adjacent to the Hazardous Waste Management Area (designated as a mixed waste area in the Laboratory's Long-Range Plan and Site Development Plan).

DETERMIMATION: Based on the analyses in the environmental assessment, the Department has determined that the construction and operation of two RCRApermitted mixed waste storage facilities does not constitute a major Federal action that would significantly affect the quality of the human environment within the meaning of the National Environmental Policy Act. Therefore, the preparation of an environmental impact statement for the proposed action is not required, and the Department is issuing this finding of no significant impact.

Issued at Washington, D.C., this $16 \underline{\underline{4}}$ day of Aucust 1994.

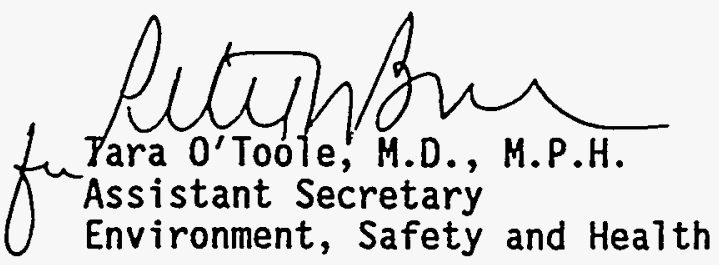




\section{ENVIRONMENTAL ASSESSMENT}

Construction of Mixed Waste Storage RCRA Facilities,

Buildings 7668 and 7669

U.S. Department of Energy

Oak Ridge National Laboratory

Oak Ridge, Tennessee

April 1994 


\section{CONTENTS}

1. PURPOSE AND NEED FOR AGENCY ACTION $\ldots \ldots \ldots \ldots \ldots \ldots \ldots \ldots$

2. DESCRIPTION OF PROPOSED ACTION $\ldots \ldots \ldots \ldots \ldots \ldots \ldots \ldots \ldots$

3. ALTERNATIVES TO PROPOOSED ACTION $\ldots \ldots \ldots \ldots \ldots \ldots \ldots \ldots \ldots$

4. LOCATION OF PROPOSED ACTION $\ldots \ldots \ldots \ldots \ldots \ldots \ldots \ldots \ldots \ldots$

5. POTENTIAL ENVIRONMENTAL IMPACTS OF PROPOSED ACTION $\ldots \ldots \ldots \ldots$

6. OPERATIONAL REQUIREMENTS $\ldots \ldots \ldots \ldots \ldots \ldots \ldots \ldots \ldots \ldots \ldots \ldots$

7. PERSONS AND AGENCIES CONSULTED $\ldots \ldots \ldots \ldots \ldots \ldots \ldots$

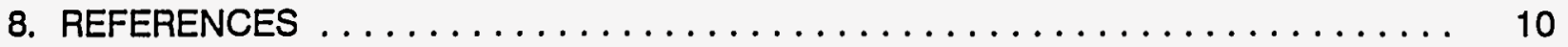




\section{FIGURES}

Fig. 1. Diagram of Hazardous Waste Management Area showing site for proposed Buildings 7668 and $7669 \ldots \ldots \ldots \ldots \ldots \ldots \ldots \ldots \ldots$

Fig. 2. Department of Energy Oak Ridge Reservation boundaries $\ldots \ldots \ldots \ldots \ldots$. 5

Fig. 3. Location of DOE Oak Ridge Reservation with respect to geographic region $\ldots \ldots \ldots \ldots \ldots \ldots \ldots \ldots \ldots \ldots$

Fig. 4. Melton Valley site for proposed mixed waste storage RCRA facilities $\ldots \ldots \ldots \ldots \ldots \ldots \ldots \ldots \ldots \ldots, 8$ 


\section{PURPOSE AND NEED FOR AGENCY ACTION}

Existing mixed waste storage facilities at the Oak Ridge National Laboratory (ORNL) are nearing capacity due to the imposition of a moratorium on off-site shipments. The moratorium has been in effect since May 1991 and precludes unrestricted off-site shipment of DOE radioactive waste. The moratorium will remain in effect on all waste shipments until operational readiness reviews are performed certifying that no radionuclides have been added to the waste by DOE activities. Results of a study (Ref. 1) assessing the mixed waste generation rate, storage capacity, and disposal capability at ORNL show that (1) the current generation rate is twice that of previous estimates; (2) the existing storage facility, Building 7654 (Long-Term Hazardous Waste Storage Facility), is nearing its storage capacity; and (3) off-site disposal facilities are not available for mixed wastes. Since the completion of the study, Envirocare of Utah, a commercial facility in Clive, Utah, has been licensed to accept mixed waste. Additional facilities need to be provided for the interim storage of ORNL-generated mixed waste (radioactive and hazardous) until disposal decisions can be made.

\section{DESCRIPTION OF PROPOSED ACTION}

The proposed action is to construct and operate two additional single-story buildings (which would augment the existing storage area) with a combined storage capacity of 750 55-gal drums, in accordance with Resource Conservation and Recovery Act (RCRA) requirements, for use as additional storage for low-level radioactive $(<10 \mathrm{mrem} / \mathrm{h})$ mixed waste. Decommissioning and decontamination and/or closure of these facilities would be addressed in the future in conjunction with action for the entire Hazardous Waste Management Area (HWMA).

The proposed facilities would be approximately 40 feet wide by 95 feet long by 16 feet high at the eaves (Building 7668) and approximately 40 feet wide by 50 feet long by 15 feet high at the eaves (Building 7669). Both buildings would be constructed to meet RCRA permitting criteria for storage of hazardous waste. The buildings would be insulated, preengineered, metal buildings of rigid frame construction with steel siding panels and metal liner panels with interior insulation (i.e., between the siding and the liner). The interior of the buildings would be open with no partitions or center support columns, and the floor area would be constructed of concrete pads (three in each building) with 4-inch-high curbs and a sump for each pad. The foundation of the buildings would be concrete column footings connected with a continuous perimeter grade beam. Access doors would be hollow metal double doors, 6 feet wide by 8 feet high, to provide forklift truck and personnel access on each side of the building. The proposed facilities would include a heating, ventilating, and air conditioning system for temperature control.

The standard types of construction equipment, such as a fuel-powered forklift truck, bulldozers, and backhoes, would be used for the proposed action. All construction activity would comply with applicable safety and health standards. Precautions would be taken to protect workers engaged in construction activities (DOE 5480.1B, Environment, Safety, and Health Program for DOE Operations), such as adequate provision for emergency aid, programs for training, and certification of safe operation and proper maintenance of equipment. The facilities would be designed to comply with DOE Order 6430.1A, General Design Criteria. The Safety Assessment for the Mixed Waste Storage Facility, Building 7669 (Ref. 2), addresses design, construction, operations, and accident assessment in detail. Construction of the buildings would involve standard construction hazards which would be mitigated by adherence to industrial safety regulations related to construction work. 
The building site for Building 7668 is relatively level and is covered with asphalt cement paving. The building site for Building 7669 is slightly elevated with a rolling topography. Site grading and excavation include nominal earthwork to achieve proper grade and drainage and for building vehicular access from the existing paved access on each side of the buildings. Although unlikely, it is possible that radioactively contaminated soils could be encountered during subsurface excavation. If encountered, radioactively contaminated soil would be detected by routine soil surveys and would likely consist of one or more of the radionuclides ${ }^{90} \mathrm{Sr},{ }^{60} \mathrm{Co}$, ${ }^{241} \mathrm{Am},{ }^{239} \mathrm{Pu},{ }^{240} \mathrm{Pu}$, or ${ }^{137} \mathrm{Cs}$ in low concentration. Any contaminated soil encountered would be handled and properly stored at existing facilities located in the HWMA according to standard ORNL procedures in a manner commensurate with the volume to be disposed of and the level of contamination. This determination would be made by personnel of Office of Radiation Protection, Field Interface and Oversight Section (FIOS), and Waste Management Operations. Hazardous contaminants are not expected to be found in the excavated soil; if encountered, however, they would be removed from the sites and properly stored at existing facilities. All nonradioactive, nonhazardous debris generated during the construction phase of the proposed project would be collected at the sites and transferred to the Y-12 Centralized Sanitary Landfill on Mt. Vernon Road for disposal.

Should construction equipment require cleaning or washing prior to removal from the sites, this activity would be done only with the approval of a FIOS representative and in areas designated by the FIOS representative. This applies to all equipment, uncontaminated as well as contaminated.

The mixed waste would be stored on the diked concrete pads according to its compatibility and stacked on 4-foot by 4-foot pallets no more than two drums high. The new facilities would be sized to hold a total of 75055 -gal drums or 41,250 gal of mixed waste. The maximum weight of each drum would be approximately 500 pounds. Building 7668 would store about 500 drums; Building 7669 would store about 250 drums, with 4 drums to a 4-foot by 4-foot pallet, stacked 2 drums high. The pallets would be moved by forklift to their storage location. One air exchange per hour would be provided in each building, and the ventilation exhaust would pass through a high-efficiency particulate air filtration system. Operation of the facilities would involve off-loading of mixed waste drums from a transport vehicle, and movement of this waste to its storage location would be accomplished by the use of a forklift. Operation would also include carrying out routine inspections and monitoring procedures and implementing necessary building maintenance measures.

Mixed waste transported to the facilities would be packaged in Department of Transportation-approved containers at the generation site. Prior to storage at the HWMA, drums containing mixed waste would be inspected for proper labeling, hazardous waste content, and radioactive contamination level. The new facilities would be used to store drums of mixed waste until authorized by the state of Tennessee and the U.S. Environmental Protection Agency to dispose of these hazardous wastes.

Four storage buildings now exist in the HWMA (see Fig. 1). Building 7654, used for longterm storage of flammable low-level mixed waste, is at its capacity of 16,500 gal. Building 7652 , used for storage of hazardous waste which has been packaged, labeled, and marked in accordance with Department of Energy (DOE) regulations, is at $85 \%$ of its capacity of 15,125 gal. Building 7653, used for storage of chemical waste, is at $95 \%$ of its capacity of 6,875 gal. Building 7651 , used to store clean oil, is at $40 \%$ of its capacity of 7,040 gal. 


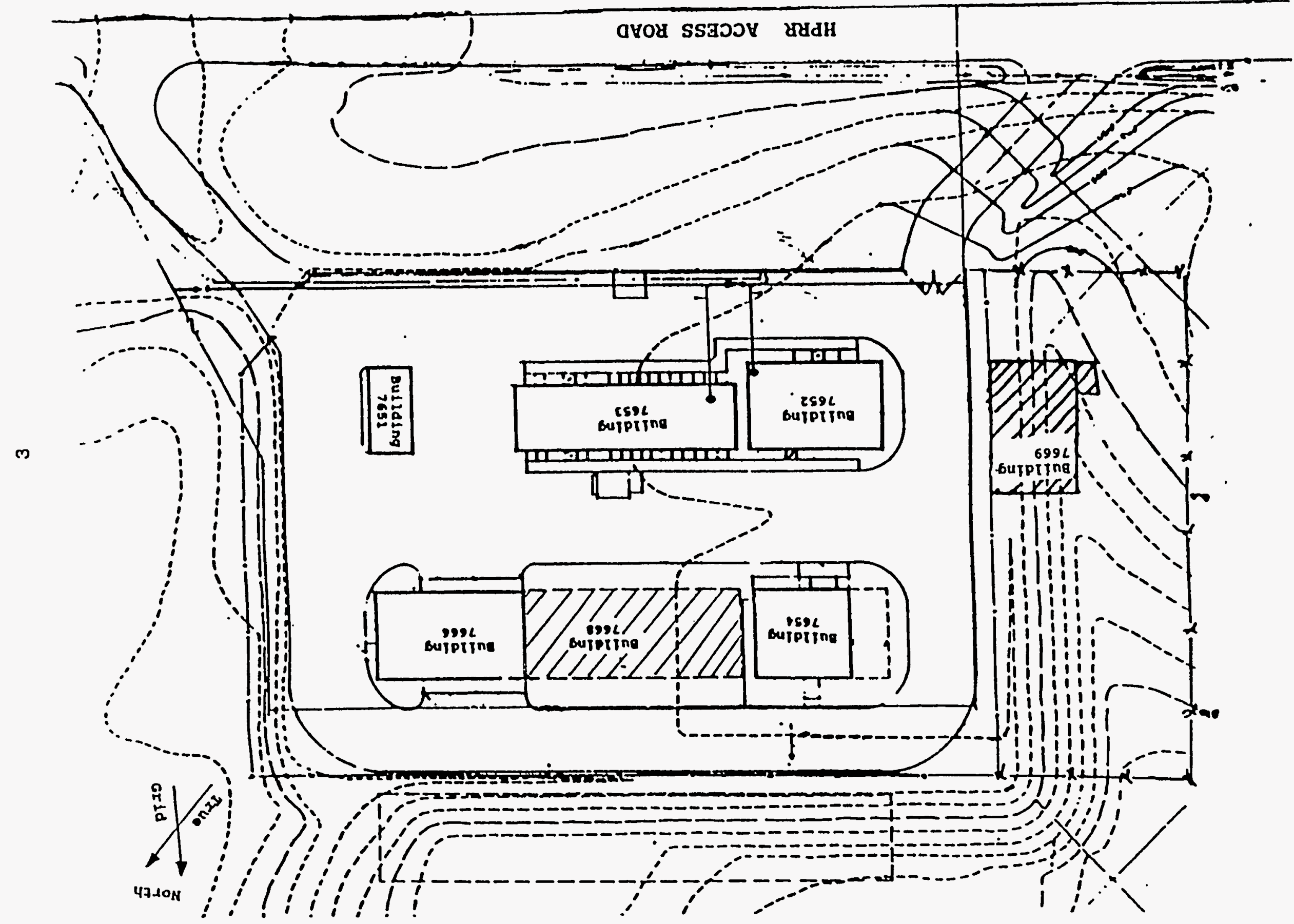


Mixed waste at the HWMA is now stored according to RCRA-approved procedures and guidelines. Prior to construction, the usual excavation and penetration permits would be required. The proposed mixed waste storage area would operate in the same manner under RCRA interim status after construction is completed. The ORNL RCRA Part A Permit application would be updated to include information about the proposed facilities, and a RCRA Part B application would be prepared for the new facilities. Activities would be in compliance with applicable state and local statutory and regulatory requirements, including permitting requirements.

\section{ALTERNATIVES TO PROPOSED ACTION}

\subsection{NO ACTION}

Because existing RCRA-permitted storage facilities are nearing capacity and mixed waste generation cannot be curtailed due to the mandatory environmental restoration activity at ORNL, the no-action alternative would result in the storage of mixed waste in facilities without RCRA permits, thus placing ORNL in violation of federal and state law. Additionally, any delay in the proposed action would seriously aggravate the existing shortage of RCRA-permitted space for mixed waste at ORNL and would compromise the permitted status of the existing Long-Term Hazardous Waste Storage Facility by adding waste to a facility that has exceeded its permitted capacity.

The no-action alternative was dismissed from further consideration because it would result in noncompliance with RCRA requirements.

\subsection{ALTERNATIVE SITES}

Alternatives to the proposed building sites were dismissed from further consideration for the following reasons: (1) The Long-Range Plan and Site Development Plan identified the HWMA as a mixed waste area; (2) the proposed Building 7668 site is located within the HWMA, is completely paved to allow for easy movement of trucks and equipment, has a security fence and gate, and has an emergency response facility on-site; (3) the proposed Building 7669 site is a previously disturbed area located immediately west of the security-fenced region of the HWMA (see Fig. 1) (this site, which was disturbed during construction of existing hazardous waste management facilities, would require minimum development; and the security fence and gate, as well as the emergency response facility, would be provided to Building 7669); (4) no other potentially available sites at ORNL have these improvements (in addition, construction of the proposed buildings at an alternative site would require extensive paving and removal of vegetative cover); and (5) the HWMA presently satisfies RCRA standards based on current issued permits.

\section{LOCATION OF PROPOSED ACTION}

The ORNL $X-10$ facilities, which are centrally located on the Oak Ridge Reservation (ORR) (Fig. 2), lie primarily in two valleys: Bethel Valley and, to the south of Bethel Valley, Melton Valley. The major ORNL facilities are clustered in Bethel Valley, and the satellite facilities are more widely separated from each other in Melton Valley. Fig. 3 shows the location of the DOE ORR with respect to the geographic region. 


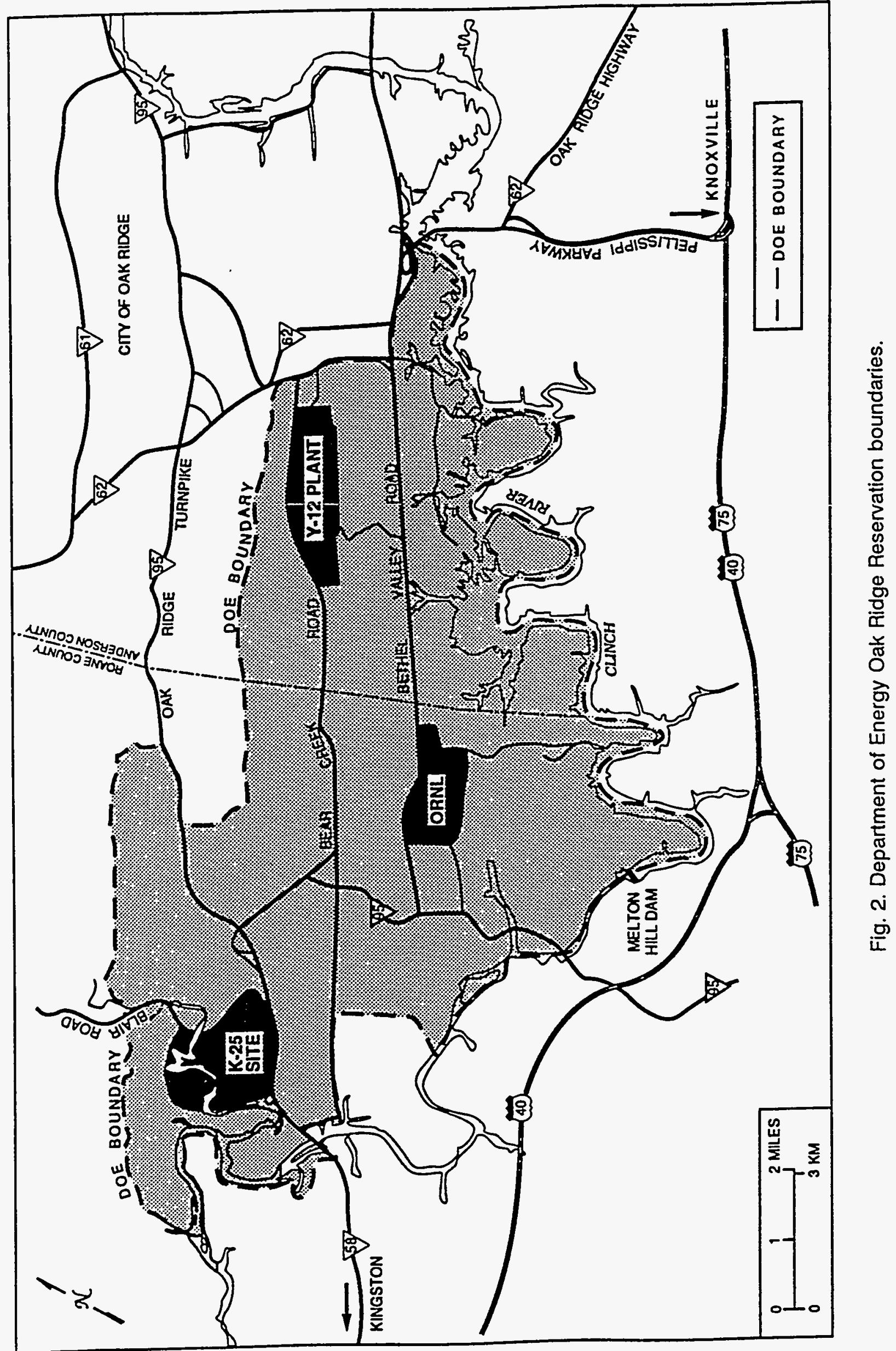



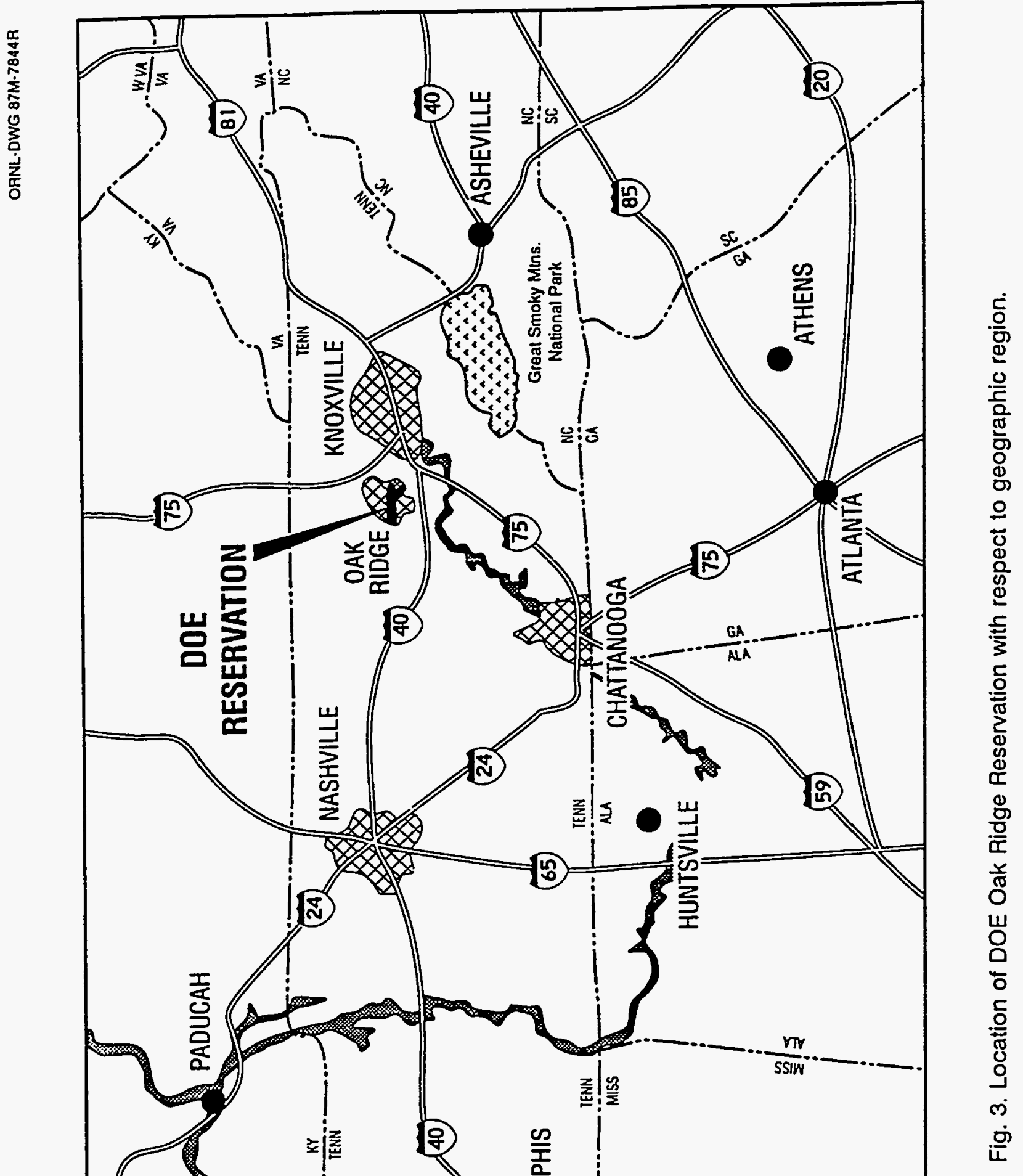
The proposed action would take place inside and immediately west of the security-fenced area of the ORNL HWMA, a 1.66-acre plot of land. The location of the HWMA (and, as a consequence, the location of the proposed storage building sites) is in accordance with ORNL's Waste Management Plan. The HWMA complex is in a level area which rises gently to the north. It is drained on the northeast by Bearden Creek and on the southeast by Bluff Creek, both of which flow into Melton Hill Lake. Building 7668 would be located between Building 7654 and Building 7666 at the HWMA; Building 7669 would be located in a previously disturbed area immediately west of the existing security fence, which would be extended to enclose the new facility (Figs. 1 and 4).

\section{POTENTIAL ENVIRONMENTAL IMPACTS OF PROPOSED ACTION}

The site for Building 7668 is located between two existing buildings (Fig. 1) and is paved with asphalt cement. The site for Building 7669 is located in a previously disturbed area next to the HWMA complex. The proposed sites do not provide a natural habitat for any known threatened or endangered animal or plant species (Refs. 3 and 4) and are outside the existing boundaries of known floodplains and wetlands (Ref. 5). No objects of archeological or historical significance are known to exist at the sites of the proposed buildings (Ref. 6).

Existing surface water drainage patterns would be minimally altered as a result of the construction activities, since no surface streams are in the immediate area. Because terrain alterations would be performed above the water table, no impacts would occur to the groundwater.

Only minor air quality impacts would be expected as a consequence of construction. Pollutant emissions during construction would be temporary and would consist primarily of particulates released during earth-moving activities. Appropriate dust suppression techniques, such as light wetting of the soil during dry, windy weather, would be utilized.

During construction of the new facilities, the potential exists for spills of liquids, including hydraulic fluid and lubricating oil. Project personnel would be familiar with spill prevention, control, containment, and cleanup measures; and spill control and cleanup materials would be maintained at the site. All mechanical equipment would be checked daily to ensure that all liquidcontaining systems are leak free and are operating properly. For systems that could not be maintained leak free, leakage rates would be maintained as low as reasonably achievable (ALARA). Containment and cleanup methods would be employed to avoid or minimize releases to the environment. Spills would be managed in accordance with The Spill Prevention, Control, Countermeasures and Contingency (SPCCC) Plans for the ORNL (ORNL-5946), the RCRA Part B Permit Applications for the operating units, and/or the ORNL Emergency Manuals.

No new transportation or operations would be introduced by the proposed action; nor would the actions present any new hazards to the environment, operations, operators, or the public. The occupational exposure from handling mixed waste in the new facilities is expected to be similar to that of existing operations. The radiation source hazard associated with the mixed hazardous wastes is considered to be "generally acceptable" and are expected to be low for normal operation. A safety analysis report would be prepared prior to facility start-up. This report will document specific operational conditions necessary to ensure the facility is in compliance with applicable DOE orders and other applicable safety criteria, such as inventory limits and required safety equipment. The proposed facility would be operated in accordance with DOE 


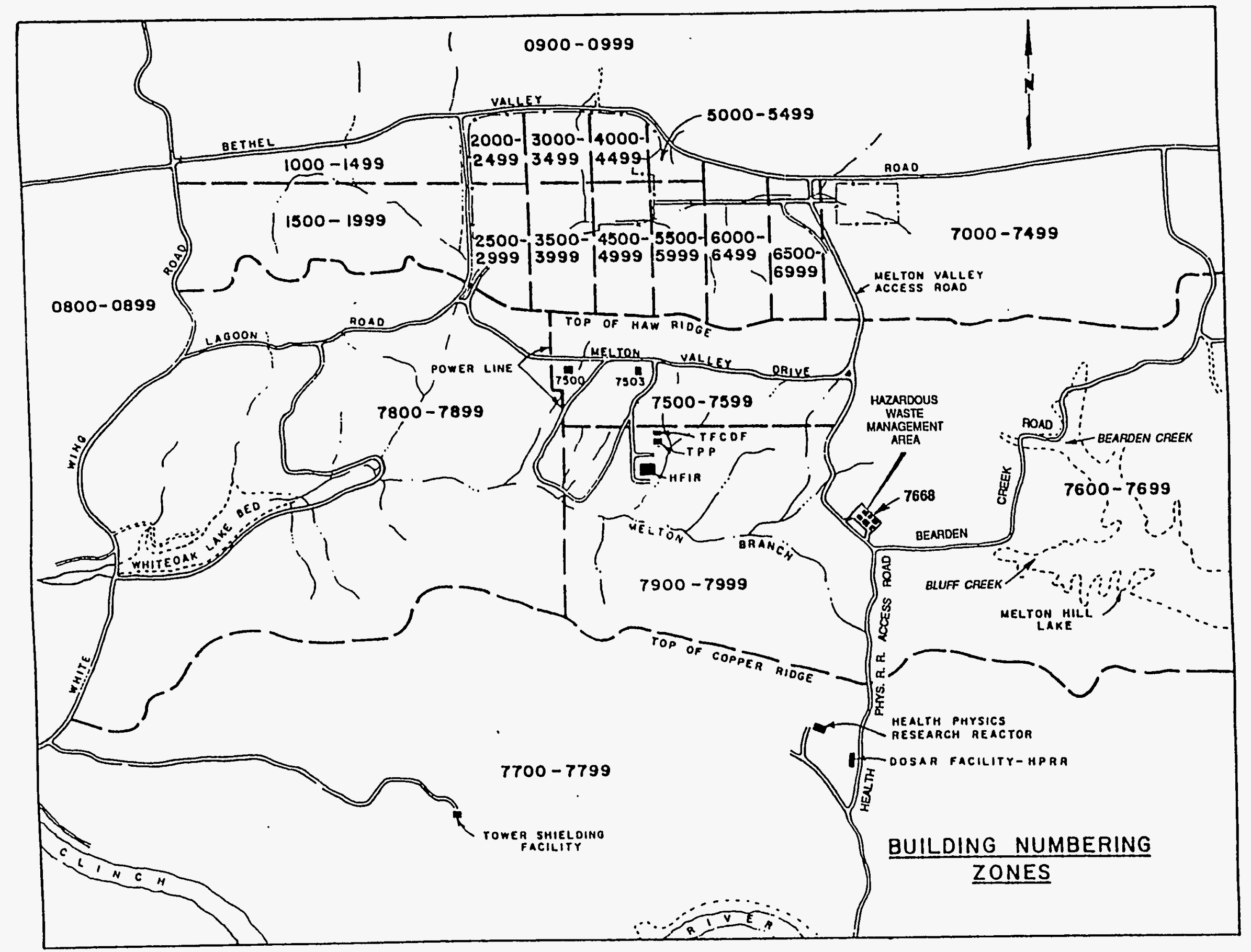

$\infty$

Fig. 4. Melton Valley site for proposed mixed waste storage RCRA facilities. 
environmental, safety, and health (ES\&H) requirements. Any specific additional requirements from the Safety Analysis Report (SAR) would be incorporated into operational procedures. Operations would comply with DOE orders regarding safety and management of storing mixed waste.

Waste would be stored in containers approved for mixed and hazardous waste and would be limited to a maximum dose rate of $<10 \mathrm{mrem} / \mathrm{h}$ on the outside surface of the waste container. The operational exposures for the HWMA facilities are monitored using personal thermoluminescence dosimeters, and ORNL policy limits exposure to no more than 2 rem/year for each employee. In 1990, the average occupational dose rate for waste workers was 22 mrem; the maximum occupational dose received by an individual worker was $149 \mathrm{mrem}$; and the minimum was 0 mrem (Ref. 7). This is well below DOE's occupational radiation dose limit of $5 \mathrm{rem} /$ year established in DOE Order 5480.11. Routine occupational exposure from day-to-day operations are to be addressed in the updated SAR. However, those exposures would not be different from the current facilities daily occupational exposure.

The hazards identified with operating the proposed 7668 and 7669 facilities are the same as those encountered with the Long-Term Hazardous Waste Storage Facility, Building 7654 (Ref. 8), since the same drummed co-contaminated wastes are being stored in Building 7654 as would be stored in Buildings 7668 and 7669 . Building 7654 has undergone a hazard screening, resulting in a determination that radiation dose coinsequences of an accident at $100 \mathrm{~m}$ would be much less than $10 \mathrm{rem}$. This would result in a cancer risk of less than $5 \times 10^{-3}$ lifetime cancer risk to on-site personnel beyond $100 \mathrm{~m}$ downwind and much less than $5 \times 10^{-5}$ to off-site members of the public for one-time exposure to accidental releases from Building 7654. To ensure the low risk, radionuclide activity limits must be below $17,390 \mathrm{Ci}$ of ${ }^{90} \mathrm{Sr}$ equivalent.

Based on a typical inventory, chemical hazards were also investigated. The chemicals expected to be stored in Buildings 7668 and 7669 are considered toxic chemicals; no carcinogens would be stored in these facilities. Exposure of personnel to toxic contaminants from the proposed storage facilities is not anticipated. Therefore, no adverse effect on workers, or the public, is expected from the hazardous components of the mixed waste to be stored under the proposed action.

Buildings 7668 and 7669 would be operated under RCRA permits. The permits require facilities to comply with 40 CFR 265 (or applicable state regulations) which specifies minimum standards for safe operations, including areas such as security, personnel training, and alarm systems. Prior to operation of either facility, the permits would be reviewed to determine if any additional safety documentation, training, or equipment would be required to comply with the permit requirements. Any required changes would be made prior to operation to ensure that the facilities are in compliance with permit requirements.

\section{OPERATIONAL REQUIREMENTS}

Buildings 7668 and 7669 would be limited to less than $17,390 \mathrm{Ci}$ of ${ }^{90} \mathrm{Sr}$ equivalent to ensure a low risk, as stated in the scenario above. Prior to operation of Building 7668 or Building 7669, the Part B permit documentation and the permit review and approval process for a final safety analysis report (FSAR) would be examined to determine the need for any additional safety documentation. Should any be required, it would be presented prior to operation of the facility. 


\section{PERSONS AND AGENCIES CONSULTED}

No regulatory agencies were required to be consulted as part of the proposed action because the proposed site is in a previously developed and permitted area. Furthermore, surveys conducted in 1991 at the site of the proposed action found no threatened or endangered plant or animal species present (Ref. 3) and no archaeological, cultural, and/or historical sites within the boundaries or adjacent to the proposed project (Ref. 6).

\section{REFERENCES}

1. ORNL Mixed Waste Generation Rate/Storage Capacity Assessment (draft), Environmental Restoration and Facilities Upgrade Program, April 1987.

2. Safety Assessment, Mixed Waste Storage Facility, Building 7669, ORNL/ENG/SA-2258/R0, Martin Marietta Energy Systems, Inc., Oak Ridge, Tenn., August 1992.

3. R. L. Kroodsma, Environmental Sciences Division, Oak Ridge Natl. Lab., Oak Ridge, Tenn., "Threatened and Endangered Animal Species at the Site of the Expanded Mixed Waste Storage RCRA Facility," internal correspondence, Aug. 21, 1991.

4. P. D. Parr, Resource Management Plan for the Oak Ridge Resenation, Vol. 4: Endangered and Threatened Plant Species, ORNL-6026/N4, Oak Ridge Natl. Lab., Oak Ridge, Tenn., July 1984.

5. M. Cunningham and L. Pounds, Wetlands on the Oak Ridge Reservation (draft), March 1991.

6. G. D. DuVall, Archaeologist, An Archaeological Reconnaissance of the Advanced Neutron Source Project on the Oak Ridge Reservation, Anderson and Roane Counties, Tennessee, prepared for Martin Marietta Energy Systems, Inc., Oak Ridge, Tenn., July 1991.

7. J. A. Setaro, Office of Environmental Health Protection, Oak Ridge Natl. Lab., Oak Ridge, Tenn., personal communication to D. L. McCorkle, Sept. 19, 1991.

8. Phase 1 - Safety Analysis Report (SAR) Update Program Hazard Screening, Long-Term Hazardous Waste Storage Facility, Building 7654, HS/7654/F1/RO, Martin Marietta Energy Systems, Inc., Oak Ridge, Tenn., November 1992. 